\title{
PERUBAHAN PARADIGMA PENELITIAN PADA ILMU KOMUNIKASI
}

\author{
Mirza Shahreza (1362170021)
}

\begin{abstract}
The purpose of this paper is to describe and compare a new and old paradigm in the context of communication science. The paradigm (approach, perspective, method, theory) of communication science has entered several phases of change. These phases are categorized and presented in different terms by experts who describe social reality. The categories are: first, pre-positivism begins at the time of Aristotle (350 BC) to David Hume (1750), both positivism, and third postcapositivism. Broadly divided into two categories, namely objective approach (behavioristik and structural) and subjective approach (phenomenolgis or interpretative). These scholars cite with different (perspective) terms, but may refer to the same intent, otherwise the same term sometimes has a different meaning, depending on who mentions the perspective.
\end{abstract}

\section{Pendahuluan}

Ilmu komunikasi adalah disiplin ilmu yang lahir dari berbagai disiplin ilmu, menurut Wilbur Schramm (1980) dibidani oleh empat orang yang sangat berpengaruh yang disebut sebagai the fouding fathers studi ilmu komunikasi, yaitu: 1) Paul Lazarsfeld (disiplin ilmu psikologi); 2) Kurt lewin (disiplin ilmu psikologi); 3) Harold D. Laswell (disiplin ilmu politik). 4) Carl Hovland (disiplin ilmu psikologi). Lasewell (1902 -1980) menjadi satu-satunya yang berlatar belakang disiplin ilmu politik yang semasa hidupnya mengalami dua peperangan dunia pertama dan kedua, sehingga mempengaruhi berbagai tulisannya dalam bidang politik sampai pada tahap kajian khusus mengenai proses komunikasi dalam dunia politik (Shahreza \& El-Yana, 2016). Selanjutnya juga ada pakar disiplin ilmu matematika, seperti Claude Elwood Shannon (matematikawan dan insinyur listrik), Warren Weaver (matematikawan dan ilmu administrasi), lalu bidang sosiologi, seperti Max Weber, George Herbert Mead, Everett Mitchell Rogers (sosiologi pedesaan) dan juga konsep-konsep atau teori antropologi yang ikut membangun ilmu komunikasi terkait pengembangan kajiannya, seperti komunikasi kelompok, organisasi dan komunikasi antarbudaya, komunikasi politik, komunikasi pembangunan, public relations, dan seterusnya.

Menurut Frank Dance (dalam Mulyana, 1999: 23), disiplin ilmu komunikasi memang tidak punya "grand theories", namun mempunyai sejumlah teori parsial dan banyak teori yang partikularistik. Alasannya karena realitas komunikasi itu rumit, 
yang ditandai dengan: 1) sifat prosesual komunikasi yang menyulitkan prediksi; 2) sifat omnipresent dan ubiqutous (ada di mana-mana) komunikasi yang membuat penjelasan menjadi sulit; 3) fakta bahwa komunikasi adalah instrumen dan objek studi; 4) kekakuan dan pelecehan yang berasal dari perdebatan paradigmatik; 5) persaingan antara disiplin-disiplin yang berkaitan. Selanjutnya Theodore Clevenger Jr (dalam Litlejohn \& Foss, 2009: 4) mencatat bahwa "masalah yang selalu ada dalam mendefinisikan komunikasi untuk tujuan-tujuan penelitian atau ilmiah berasal dari fakta bahwa kata kerja "berkomunikasi" memiliki posisi yang kuat dalam kosakata umum dan karenanya tidak mudah didefinisikan untuk tujuan ilmiah." Sebenarnya, kata kerja ini merupakan salah satu istilah dalam bahasa Inggris yang sering digunakan. Para akademisi telah mencoba segala usaha untuk mendefinisikan komunikasi, tetapi menentukan sebuah definisi tunggal terbukti tidak mungkin dilakukan dan tidak akan berhasil.

Selanjutnya Frank Dance (Litlejohn \& Foss, 2009) mengambil sebuah langkah besar dalam mengklasifikasi konsep kasar ini dengan menggarisbawahi sejumlah elemen yang digunakan untuk membedakan komunikasi. Ada tiga poin penting dari perbedaan konseptual yang membentuk dimensi-dimensi dasar komunikasi. Dimensi pertama, yaitu tingkat pengamatan atau keringkasan. Beberapa definisi termasuk luas dan bebas; yang lainnya terbatas. Sebagai contoh, definisi komunikasi sebagai "proses yang menghubungkan semua bagian-bagian yang terputus." Merupakan definisi yang umum. Definisi yang lain, komunikasi sebagai "sebuah sistem" (misalnya telepon, telegraf) untuk menyampaikan informasi dan perintah, misalnya di Angkatan laut," bersifat membatasi. Namun perkembangan teknologi terkini adanya saluran sistem yang multikoneksi, yaitu internet dan media sosial. Dimensi kedua, adalah tujuan. Komunikasi adalah proses penyampaian dari pengirim pesan (sender) kepada penerima pesan (receiver) dengan tujuan tertentu untuk mempengaruhi penerima pesan. Namun, tujuan juga bisa berbentuk untuk menyamakan persepsi atau pemahaman di antara pengirim dan penerima pesan. Dimensi ketiga, dengan penilaian normatif. Tujuannya adalah untuk dapat membedakan beberapa definisi komunikasi. Misalnya, beberapa definisi menyertakan pernyataan tentang keberhasilan, keefektifan, ketepatan, disisi definisi lain tidak berisi penilaian lengkap seperti itu. Contohnya adalah komunikasi dikatakan berhasil jika "komunikasi merupakan pertukaran sebuah pemikiran atau gagasan." Asumsi dari pemikiran ini adalah sebuah gagasan atau pemikiran berhasil ditukarkan. Di sisi lain, sebuah definisi yang tidak menilai apakah hasilnya berhasil atau tidak: "Komunikasi adalah penyampaian informasi. Di sini, informasi disampaikan, tetapi tidak penting apakah informasi tersebut diterima/ difahami atau tidak. Kesimpulan Dance adalah komunikasi mencakup banyak hal dan dia memilih sekumpulan konsep daripada teori atau gagasan tunggal yang mendefinisikan komunikasi secara kolektif. 


\section{Rumusan Masalah}

Tulisan ini akan menjawab soal yang merupakan salah satu tugas Ujian Tengah Semester mata kuliah Filsafat Sains program S3 Institut Pertanian Bogor, yaitu merumuskan dan menganalisis salah satu perubahan paradigma penting dalam ilmu komunikasi, yaitu:

1. Ontologi, epistemologi, dan aksiologi pada paradigma lama.

2. ketidakpuasan pada paradigma lama dan akibatnya.

3. Faktor yang mendukung perubahan paradigma tersebut.

4. Ontologi, epistemologi, dan aksiologi pada paradigma baru.

5. Tokoh-tokoh dan lembaga pendukung paradigma baru tersebut.

6. Proses "pengujian" terhadap paradigma baru.

\section{Tinjauan Pustaka}

\section{Paradigma}

Paradigma menurut Kuhn (Lubis, 2016: 166) secara umum adalah beberapa contoh praktik ilmiah aktual yang diterima seperti: hukum, teori, aplikasi dan instrumen yang diterima bersama, sehingga merupakan model yang dijadikan sebagai sumber dan tradisi-tradisi yang kokoh dalam riset-riset ilmiah khusus. Paradigma berarti "pola", "model", atau "skema" dan "pemahaman" aspek-aspek tertentu ihwal realitas (kenyataan) yang dikaji. Kelebihan paradigma (metateori) untuk membedakan beragam metodologi dengan begitu jelasnya sehingga dengan mudah mampu membedakan suatu teori, konsep, metodologi, dan aksi antara yang satu dari yang lainnya (Agusta, 2014: 6). Menurut Kuhn (dalam Agusta, 2014) paradigma menunjuk kepada dua hal. Pertama, suatu pandangan tertentu terhadap suatu entitas atau bisa dinyatakan sebagai sisi ontologis entitas tersebut. Sisi ontologis paradigma kritis, misalnya melihat keberadaan represi kekuasaan dalam sejarah suatu komunitas. Kedua, suatu perilaku dari entitas tersebut yang mencakup metodologi maupun instrumen atau peralatan yang dibutuhkan untuk menggalinya, sampai kepada aksiologi beserta sekelompok orang pendukung paradigma yang dianut tersebut.

Paradigma tentang metodologi diperlukan karena komponen di dalamnya adalah komponen ontologi, epistemologi, dan aksiologi untuk melakukan pembedaan antarmetodologi pada tataran metateoretis beradasarkan paparan Lincoln \& Guba (2000) ; Schwandt (2000) dalam Agusta (2012: 7). Konsep paradigma semula digunakan untuk menjelaskan perkembangan suatu teori baru dengan cara menjatuhkan paradigma teoritis sebelumnya (revolusi ilmiah), bukannya mengakumulasi keseluruhan hasil teori-teori sebelumnya (evolusi ilmiah). Suatu teori baru akan menggantikan secara total pandangan ontologis, metodologis, 
sampai aksiologis teori sebelumnya. Proses revolusi ilmiah dimulai dari kondisi praparadigma. Pada saat seperti ini temuan-temuan fakta, yang banyak sekalipun, tidak bisa disusun secara sistematis karena tidak memiliki panduan metateoritis untuk mengurutkannya hingga berarti. Setelah bisa didefinisikan secara sistematis menurut ontologi, epistemologi, dan aksiologi dari kajian tersebut, temuan fakta menjadi bermakna untuk disusun menjadi teori. Kondisi menuju ilmu normal ini menunjukkan tanda awal susunan paradigma yang muncul. Dengan adanya paradigma proses pengumpulan fakta atau informasi menjadi terarah sehingga tidak perlu mengumpulkan terlalu banyak fakta atau informasi melainkan cukup ragam fakta atau informasi yang bisa dijelaskan oleh paradigma tersebut. Penguatan ilmu normal ditunjukkan oleh pengumpulan fakta atau informasi semacam ini yang akan disimpulkan untuk menguatkan paradigma yang dimaksud (Agista, 2014).

Kuhn menerima pluralitas paradigma. Pluralitas berarti setiap paradigma mempunyai aturan dan kriteria kebenarannya masing-masing. Sehingga, satu kriteria paradigma (teori/ kebenaran) tertentu tidak bisa dipaksakan untuk menilai paradigma lainnya. Artinya, aturan dan kriteria antar satu paradigma dengan paradigma lain tidak sepadan atau tak terbandingkan karena tidak ada satu pengertian atau kriteria umum yang sama-sama diterima oleh pelbagai paradigma. Inilah yang disebut dengan istilah ketidaksepadanan (incommensurability) menurut Kuhn (Lubis, 2016: 168). Paradigma bisa dapat pula terjadi pergeseran (peralihan) atau pergantian (paradigm shift) karena adanya perkembangan atau dinamika sosial dan teknologi. Pergeseran paradigma (ilmiah) mengandung beberapa unsur pengertian diantaranya, yaitu: 1) munculnya cara berpikir baru mengenai masalahmasalah baru; 2) dalam paradigma ada prinsip (asumsi) yang selalu hadir, akan tetapi tidak kita kenal / sadari; 3) paradigma baru tidak dapat diterapkan kecuali dengan meninggalkan paradigma lama; 4) paradigma baru selalu dihadapi / ditanggapi dengan kecurigaan dan permusuhan (Lubis, 2016: 169).

\section{Ontologi}

Ontologi adalah salah satu cabang dari filsafat yang pada intinya mempertanyakan Apa? (What it is?). Ontologi adalah studi tentang makna dari "ada" dan "berada". Ciri-ciri esensial dari yang ada dalam dirinya sendiri, menurut bentuknya yang paling abstrak (Suparlan, 2005). Pengertian ontologi adalah memahami hakikat jenis ilmu pengetahuan itu sendiri yang dalam hal ini adalah ilmu komunikasi. Ilmu komunikasi dipahami melalui objek materi dan objek formal. Secara kacamata ontologis, ilmu komunikasi sebagai objek materi merupakan sesuatu yang monoteistik pada tingkat abstrak dengan kata lain yang paling tinggi sebagai sebuah kesatuan dan kesamaan sebagai makhluk atau benda.

Sementara objek formal melihat komunikasi sebagai suatu sudut pandang (point of view), yang akhirnya menentukan ruang lingkup disiplin ilmu komunikasi. Contoh ilmu komunikasi dari aspek ontologis adalah terkait dengan sejarah yang 
mengkonstruksi ilmu komunikasi, siapa saja sebagai pencetusnya (the Founding Father), bentuk-bentuk teori komunikasi, pengelompokan ilmu komunikasi (tradisitradisi dalam ilmu komunikasi) dan kajian tentang komunikasi pada manusia.

\section{Epistemologi}

Epistemologi juga merupakan cabang dari filsafat yang mempertanyakan bagaimana? (How to get it?). Pada hakikatnya berkaitan dengan 'pengetahuan', yaitu pengetahuan tentang ilmu komunikasi (Theory of knowlegde). Persoalan utama epistemologi ilmu komunikasi adalah mengenai persoalan apa yang dapat kita ketahui dan bagaimana cara mengetahuinya? Perdebatan mengenai ilmu komunikasi yang merupakan sebuah ilmu atau bukan sangat erat kaitannya dengan bagaimana proses penetapan suatu bidang menjadi sebuah ilmu pengetahuan. Sebagai ilmu, komunikasi di bangun oleh sumbangan dari berbagai disiplin ilmu sosial yang muncul lebih dahulu. Pengaruh ilmu sosiologi dan psikologi sangat memberikan kontribusi atas lahirnya ilmu komunikasi.

Selanjutnya ilmuan politik (Harold D Lasswel) pun termasuk yang mencetuskan pentingnya ada kajian atau ilmu di mana komunikasi menjadi penting seperti pada peristiwa perang dunia ke-2 di mana teknik negosiasi, lobi menjadi penting dilakukan dan dasar dari teknik tersebut adalah kemampuan berkomunikasi yang baik dan efektif. Secara aksiologi menjadi penting saat komunikasi ditelaah lebih jauh dan akhirnya ilmu komunikasi melahirkan nilai-nilai, etika yang berlaku dalam kelompok atau masyarakat. Contoh epistemologi ilmu komunikasi dapat dilihat dari sejarah perkembangan ilmu komunikasi (Griffin, 2002). Kajian komunikasi yang dipelajari untuk kepentingan manusia pada masa peperangan semakin meneguhkan komunikasi menjadi sebuah ilmu atau pengetahuan.

\section{Aksiologi}

Aksiologi adalah bagian dari filsafat yang mempunyai pertanyaan "untuk apa?" (what for?) Hakikat individual dari ilmu pengetahuan yang bersifat etik terkait aspek kemanfaatan dari ilmu itu sendiri. Tujuan pragmatik filosofis yaitu kemanfaatan dengan tujuan kepentingan manusia itu sendiri. Perkembangan ilmu komunikasi berkaitan dengan kebutuhan manusia untuk berkomunikasi. Kebutuhan mempengaruhi orang lain, teknik berbicara (retorika), berbagi informasi, adalah sebagian kecil dari manfaat ilmu komunikasi. Secara pragmatis aspek aksiologi dari ilmu komunikasi terjawab seiring perkembangan kebutuhan manusia. 


\section{Telaah Filosofis Ilmu Komunikasi}

Telaah ilmu komunikasi secara filosofis berdasarkan tiga elemen yang sudah dipaparkan sebelumnya. Pertama, berdasarkan elemen ontologis, berarti menelaah keberadaan mengenai apa yang dikaji oleh ilmu komunikasi itu. Menurut Littlejohn (Imran, 2014: 20-22), objek komunikasi itu adalah komunikasi antar manusia (human communication). Komunikasi antar manusia tersebut terjadi melalui lima tatanan yang terdiri dari: 1) antarpribadi; 2) kelompok; 3) publik; 4) organisasi; 5) massa. Maka secara ontologis ilmu komunikasi mengkaji persoalan-persoalan peristiwa komunikasi yang terjadi di dalam ke lima konteks tersebut. Dari ke lima objek kajian tersebut relevan dengan prinsip-prinsip epistemologis.

Kedua, berdasarkan elemen epistemologis. Pada prinsipnya elemen epistemologis mempelajari ilmu komunikasi dari segi bagaimana cara ilmu komunikasi dalam memperoleh kebenaran ilmiahnya. Karena menyangkut cara, maka diasumsikan akan sangat banyak cara dalam upaya ilmuwan komunikasi memperoleh kebenaran ilmiahnya. Cara-cara yang dikenal dalam upaya memperoleh kebenaran ilmiah dalam ilmu komunikasi, jika direduksi diantaranya adalah menyangkut paradigma teori dan paradigma penelitian. Paradigma teori terkait dengan penggambaran tentang asumsi yang melatarbelakangi bagaimana sutu teori itu dilahirkan. Sedangkan paradigma penelitian menggambarkan tentang bagaimana suatu proses penelitian secara ideal harus dilakukan. Paradigma teori itu biasanya cenderung akan berkaitan dengan paradigma penelitian. Selanjutnya, keterkaitan ini akan menentukan pula arah pelaksanaan penelitian, apakah akan mengarah pada pendekatan penelitian kuantitatif atau pendekatan kualitatif.

Ketiga, berdasarkan elemen aksiologi. Secara aksiologi, berarti ilmu secara filosofis berupaya menelaah ilmunya dan segi azas kegunaan ilmu pengetahuan bagi kesejahteraan umat manusia. Dalam konteks ilmu, kajian ini biasanya berhubungan dengan masalah nilai (value). Jadi pertanyaan-pertanyaan yang diajukan selalu berkaitan dengan persoalan nilai, bisa nilai-nilai sosial yang berlaku di masyarakat atau norma-norma yang ada di masyarakat. Terjadi pengkubuan terkait persoalan nilai, kubu pertama mengakui eksistensi nilai (value), kubu lainnya tidak mengakui keberadaan nilai dalam proses kerja ilmiah ilmu pengetahuan. Contoh masalah kloning manusia, ada yang tidak setuju terkait nilai dan norma, ada yang menganggap ilmu itu bekerja untuk ilmu itu sendiri dan tidak ada hubungannya dengan masalah nilai dan norma yang dipersepsikan oleh budaya yang dibangun oleh peradaban manusia (Imran, 2016). 


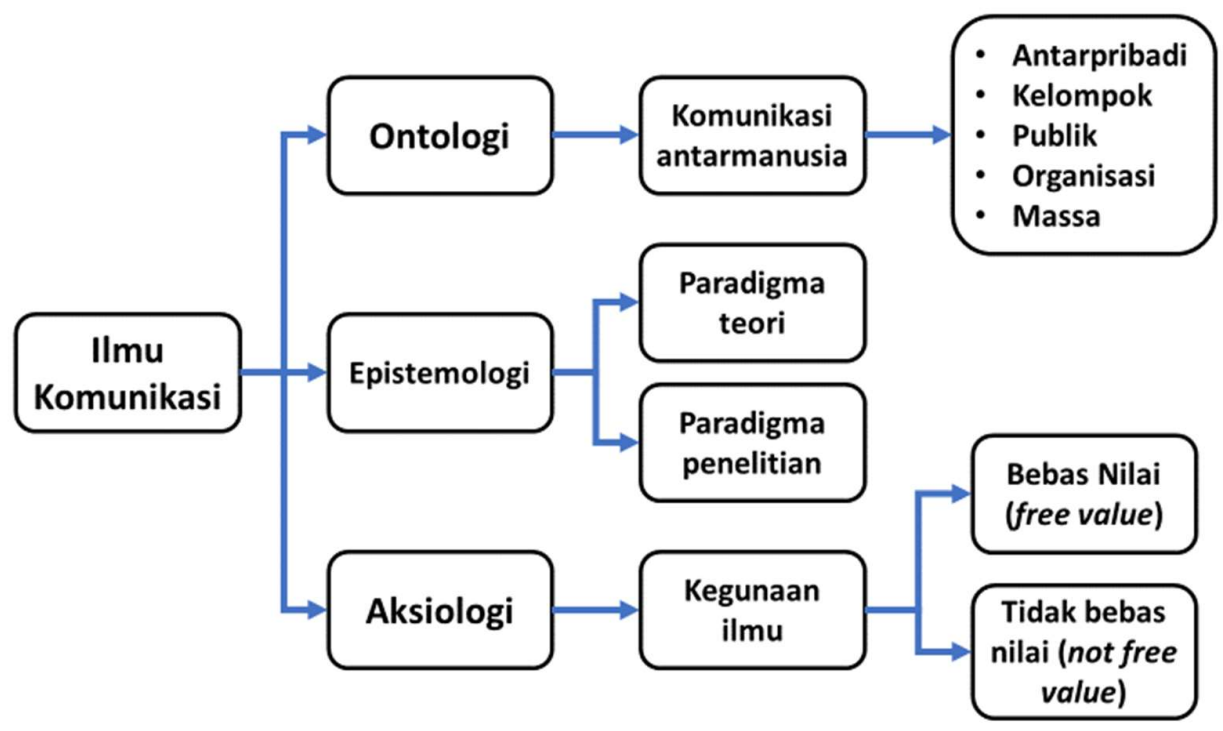

Gambar 1: Objek Kajian Filsafat Ilmu Komunikasi (Imran, 2014: 22)

\section{Pembahasan}

\section{Paradigma lama Ilmu Komunikasi}

Paradigma (pendekatan, perspektif, metode, teori) ilmu komunikasi sudah memasuki beberapa fase perubahan. Fase-fase tersebut menurut Engkus Kuswarno (2008) dikategorikan dan dipaparkan dengan istilah berbeda oleh para pakar yang menggambarkan realitas sosial. Nasution (1996) menyebut kategori tersebut, pertama pra-positivisme dimulai zaman Aristoteles (350 SM) sampai David Hume (1750), kedua positivisme, dan ketiga pascapositivisme. Guba dan Lincoln (1994) menyebutkan Classical paradigm, Critical paradigm, Constructivism paradigm. Dalam kajian ilmu komunikasi Fisher (1986) menyebutkan presepektif mekanistik, psikologis, interaksional, pragmatik, dan dramatisme. Tuker, dkk (1981) menyebut perspektif hukum peliput (convering laws perspective), perspektif aturan (rules perspective) dan perspektif sistem. Litteljohn (1996) mengemukakan teori (perspektif) struktural dan fungsional, kognitif, dan behavioral, interaksional, interpretif, dan teori kritis. Mulyana (2001) menyebutkan pendekatan objektif (behavioristik dan struktural) dan pendekatan subjektif (fenomenolgis atau interpretatif). Para pakar tersebut menyebutkan dengan istilah (perspektif) yang berbeda, tapi bisa jadi merujuk kepada maksud yang sama, sebaliknya istilah yang sama terkadang punya makna berbeda, tergantung kepada siapa yang menyebutkan perspektif tersebut.

Ilmu komunikasi adalah bagian dari ilmu-ilmu sosial, maka segala aktivitas penelitian yang dilakukan didalamnya, merupakan multi-paradigm science (Hidayat, 
1999). Teori-teori dan penelitian ilmiah komunikasi bisa dikelompokkan dalam 3 paradigma, yaitu: 1) classical paradigm (yang mencakup positivsm dan postpositivsm); 2) critial paradigm; 3) constructivism paradigm. Masing-masing paradigma sebagai mental window (world view) yang digunakan oleh suatu komunitas ilmuwan tertentu untuk mempelajari objek keilmuan mereka yang satu sama lain mungkin bisa saling melengkapi atau bisa jadi bertolak belakang dan sulit dipertemukan. Perbedaan antarparadigma tersebut dapat dilihat dalam empat dimensi, yaitu:

1. Epistemologis, yang menyangkut asumsi mengenai hubungan antara peneliti dan yang diteliti dalam proses untuk memperoleh pengetahuan mengenai objek yang diteliti.

2. Ontologis, berkaitan dengan asumsi mengenai objek atau realitas sosial yang diteliti.

3. Aksiologis, berkaitan dengan posisi value judgements, etika, dan pilihan moral peneliti dalam suatu penelitian.

4. Metodologis, berisi asumsi-asumsi mengenai bagaimana cara memperoleh pengetahuan mengenai suatu objek pengetahuan.

Paradigma lama, yaitu paradigma klasik (classic) bila ditinjau dari aspek epstemologis, ontologis, aksiologis dan metodologis adalah sebagai berikut:

Tabel 1: Paradigma Klasik (Hidayat, 2009)

\begin{tabular}{|l|l|}
\hline Epistemologis & $\begin{array}{l}\text { Dualist/ objectivist, ada realitas objektif. Sebagai suatu realitas } \\
\text { yang eksternal di luar dari peneliti. Peneliti harus sejauh mungkin } \\
\text { membuat jarak dengan objek penelitian. }\end{array}$ \\
\hline Ontologis & $\begin{array}{l}\text { Critical realism: ada realitas "real" yang diatur oleh kaidah-kaidah } \\
\text { tertentu yang berlaku universal walaupun kebenaran pengetahuan } \\
\text { tentang itu mungkin hanya bisa diperoleh secara probabilistik. }\end{array}$ \\
\hline Aksiologis & $\begin{array}{l}\text { Nilai, etika, dan pilihan moral harus berada di luar proses } \\
\text { penelitian. } \\
\text { Peneliti berperan sebagai disinterested scientist. } \\
\text { Tujuan penelitan: eksplanasi, prediksi, dan kontrol. }\end{array}$ \\
\hline Metodologis & $\begin{array}{l}\text { Interventionist: pengujian hipotesis dalam struktur hupothetico- } \\
\text { deductive method, melalui lab, eksperimen atau survei eksplanatif, } \\
\text { dengan analisis kuantitatif. } \\
\text { Kriteria kualitas penelitian: Objektivity, Realibility, dan Validity } \\
\text { (internal dan external validity). }\end{array}$ \\
\hline
\end{tabular}


Secara umum paradigma klasik sangat mendominasi berdasarkan atas sejumlah pengamatan, diantaranya: jumlah penelitian, jumlah publikasi hasil penelitian, besarnya pendanaan yang diperoleh, jumlah ilmuan, dan profesional komunikasi yang terserap industri komunikasi atau pasaran tenaga kerja sektor ekonomi lainnya. Besarnya kecenderungan di kalangan ilmuwan komunikasi sendiri untuk menilai metodologi paradigma klasik sebagai satu-satunya metodologi penelitian. Ada sejumlah faktor penopang dominasi paradigma klasik, yaitu: kedudukan ilmu-ilmu eksakta masih dinilai lebih superior dari ilmu-ilmu sosial, oleh karena itu metodologi paradigma klasik yang berorientasi pada ilmu-ilmu eksakta lebih banyak dipelajari dan dikembangkan di lembaga-lembaga pendidikan. Penelitian-penelitian yang berpijak pada paradigma klasik lebih mudah memberikan manfaat praktis, baik di dunia industri dan usaha, ataupun lembaga-lembaga perumus kebijakan publik. Paradigma klasik berpegang teguh dengan prinsip ketidakberpihakan, objketivitas, dan penolakan terhadap subjektivitas, dan juga lebih mudah memperoleh sumber bantuan daya dan dana (Hidayat, 2009).

\section{Ketidakpuasan Pada Paradigma lama}

Ketidakpuasan terhadap paradigma lama (klasik) terutama kritik yang diajukan oleh Dr. Jalaluddin Rakhmat, M.Sc yang dipublikasikan pada jurnal Ikatan Sarjana Komunikasi Indonesia (ISKI) Vol. III/April 1999. Dr. Jalaludin adalah pencetus penelitian korelasional dan memperkenalkan mata kulian Metodologi Penelitian Komunikasi (1984) yang sebelumnya lebih dikenal dengan Metodologi Penelitian Sosial setelah kepulangan dari studinya di Amerika. Saat itu penelitian korelasional dengan perhitungan statistik menjadi populer periode $1980 \mathrm{~s} / \mathrm{d}$ akhir 1990 (Mulyana \& Solatun, 2008: 416). Namun terakhir banyak tulisannya yang mengkritik paradigma positivistik. Ketidakpuasan atau kekecewaan Dr. Jalauddin Rakhmat pada paradigma positivisme dipaparkan sebanyak lima butir pernyataan, yaitu: Pertama, realitas hasil konstruksi (constructed realy). Dalam kehidupan sosial, tidak ada realitas tunggal. Yang ada adalah realitas banyak (multiple reality). Setiap aktor atau pengamat membentuk realitasnya sendiri. Ketika penelilti menyusun angket, ia sedang membuat peta realitas menurut pikirannya.

Kedua, pengamatan partisipan (partisipant observer). Positivisme menpunyai asumsi epistemologis yang memungkinkan terpisahnya pengamatan dari yang diamati (the knower from the known). Ilmuwan adalah pengamat yang objektif, independen, dan tidak berinteraksi dengan objek. Bila kemudian ada interaksi, menurut positivis, peneliti harus berusaha menyingkirkannya dengan intervensi metodologis. Padahal apa yang disebut "pengamatan yang independen dari objek yang diamatinya" sangat sukar dipertahankan dalam penelitian sosial (bahkan ilmu alamiah sekalipun). Banyak hal membuktikan adanya interaksi antara the knower dan the known; teori dan fakta tidak pernah terpisah (theory-laden facts); manusia hanya dapat diteliti dengan pengertian dan kerjasama orang yang diteliti; manusia tidak bisa tidak selalu reaktif pada manusia lain. 
Ketiga, generalisasi: tidak ada generalisasi. Positivisme mengasumsikan keterlepasan observasi dari faktor waktu dan konteks; apa yang benar pada jam satu waktu dan tempat, juga benar pada waktu dan tempat lain. Hasil dari sampel dapat dijadikan estimasi seluruh populasi. Generalisasi klasik demikian mengandung banyak kelemahan, karena bergantung pada determinisme, bergantung pada logika induktif, bergantung pada asumsi bebas dari waktu dan konteks, terjerat dalam dilema nomothetik-ideografik, terjerat dalam kekeliruan reduksionis.

Keempat, kausalitas banyak (multiple causality). Positivisme beranggapan bahwa tujuan ilmu adalah menemukan hubungan sebab-akibat. Secara falsafi, ilmu bertujuan merumuskan pertanyaan-pertanyaan nomothetik: $y=f(x)$. Akhirnya, bila kita mengetahui $x$ penyebab $y$, kita bukan saja dapat meramalkan $y$, dengan pengetahuan kita tentang $\mathrm{x}$, tetapi juga dapat mengendalikan $\mathrm{y}$. Karena kausalitas menjadi pusat perhatian alam dan menjadi deterministik. Principle of Uncertainty dan mekanika quantum telah meragukan asas kausalitas linear tersebut. Penemuan muktahir dalam berbagai bidang menunjukkan berbagai sebab dan bukan sebab tunggal, berinteraksi sesama mereka dalam menimbulkan akibat.

Kelima, sarat nilai. Positivisme didasarkan pada asusmsi aksiologis bahwa dengan metodologi ilmiah, penelitian tidak dipengaruhi oleh sistem nilai. Asusmsi ini erat kaitannya dengan asusmsi kedua. Karena peneliti terpisah dari objek yang diteliti, nilai-nilai yang dianut peneliti tidak akan mempengaruhi sifat-sifat objek yang diteliti. Ilmu, karena itu, bersifat etis. Science is netral between ends. Asumsi penelitian yang "bebas nilai" telah banyak dikritik para filsuf. Untuk ilmu sosial, kita dapat menyebut antara lain Bahn (1971), Homans (1978), Morgan dan Smirchich (1980). Nilai menentukan apa yang harus diteliti, bagaimana menelitinya, dan bagaimana menafsirkannya. Sejarah sains dipenuhi contoh-contoh betapa nilai dipengaruhi penelitian. Anggapan bebas nilai hanya dipertahankan dalam asumsi keterpisahan fakta dan teori. Peneliti dari yang diteliti, dunia fakta dan dunia nilai. Epistemolog modern menunjukkan bahwa fakta selalu "theory-laden". Jika teori ditentukan nilai dan fakta "theory-laden", maka fakta ditentukan oleh nilai.

\section{Faktor Yang Mendukung Perubahan Paradigma}

Kekecewaan terhadap positivisme sebetulnya telah dimulai, jauh ketika perkembangan fisika muktahir menantang asumsi-asumsi positivisme. Lewat penelitian cahaya, Werner Heisenberg merumuskan asas ketidakpastian (Principle of Uncertainty): "Apa yang kita amati bukan alam, tetapi alam seperti tampak pada metode penelitian kita." Kemudian, sebagai padanan mekanika quantum dalam fisika, fenomologi Husserl dan Schutz sangat mempengaruhi penelitian sosial. Objek, orang, situasi dan peristiwa tidak memiliki makna, tetapi diberi makna. Pemberian makna terjadi dalam interaksi sosial. Makna adalah hasil negosiasi. Tugas peneliti, karenanya, bukanlah memaksakan makna kepada subjek; tetapi bersama mereka, peneliti mengkonstruksi realitas. Penelitian adalah upaya menemukan "what they 
are experiencing, how they interpret their experiences, and how they themselves structure the sosial world in which they live" (Psathas, 1973). Inilah intisari paradigma pascapositivisme untuk penelitian dengan pendekatan kualitatif. Sedangkan paradigma positivisme yang menggunakan pendekatan kuantitatif, bukan saja menjadi kurang bermanfaat, bahkan bisa merusak (Rakhmat, 1999: 66).

Keterbatasan penelitian positivisme yang sangat memisahkan subjek dari habitat alamiahnya, dari natural setting-nya sehingga eksperimen sebagai tonggak positivisme menghasilkan situasi yang tidak lazim, buatan, berusia pendek, dan sukar digeneralisasikan. Padahal manusia bukan saja sangat reaktif (responsif), tetapi juga selalu mengkonstruksi realitas disekitarnya. Kaum fenomenogoli, misalnya, berusaha memasuki dunia konseptual subjek, untuk mengetahui bagaimana orang mengkonstruksi makna terhadap peristiwa-peristiwa kehidupan mereka. Fenomenologi percaya bahwa realitas adalah "socially contructed" (Berger dan Luckman, 1967). Dengan demikian, melalukan penelitian pascapositivime, berarti melanjutkan tradisi "Verstehen" dari Max Webber: "Phenomenological inquiry begins with silence" (Psathas, 1973) dalam Rakhmat (1999: 68).

Jensen (Mulyana \& Kuswarno, 2005), mengemukakan pertumbuhan paradigma kualitatif dipicu oleh dua kondisi historis. Pertama, kondisi internal dalam komunitas ilmiah, banyak pakar dan lembaga yang mempertanyakan daya eksplanatori pendekatan konvensional dalam ilmu-ilmu sosial. Terdapat konsensus banyak bahwa banyak isu penelitian tidak cukup ditelaah melalui metode positivistikkuantitatif. Kedua, kondisi eksternal di luar komunitas ilmiah, perkembangan ilmu sedikit banyak berkaitan dengan perubahan dalam bidang sosioekonomi yang lebih luas, sehingga pendekatan kualitatif diperlukan untuk beradaptasi dengan bentuk realitas sosial yang baru, yang sering disebut dengan masyarakat pascaindustri, era pascamodern, dan masyarakat informasi. Menurut Jensen, erosi pola-pola sosial tradisional dan perkembangan komunikasi massa sebagai sumber primer kohesi sosial di banyak kawasan dunia merupakan gejala abad ke-20 yang semakin cepat dalam beberapa dekade terakhir. Hal ini menuntut pencarian akan teori-teori dan metode-metode baru yang lebih kontekstual untuk memahami kompleksitas sosial dan budaya serta perubahannya. Perubahan paradigma terjadi karena realitas semakin kompleks dan penelitian kuantitatif telah gagal mengungkap realitas tersebut.

\section{Telaah Filosofis Pada Paradigma Baru}

Paradigma baru adalah antitesis dari positivis, yaitu lompatan kepada paradigma kontruktivisme dan kritis dengan penggunaan metode kualitatif dalam penelitannya. Terkait telaah filosofis yang terdiri dari ontologis, epsitemologis, dan aksiologis serta ditambah metodologis sebagaimana akan dipaparkan pada tabel dibawah ini. 
Tabel 2: Paradigma Baru: Konstruktivis dan Kritis (Hidayat, 1999)

\begin{tabular}{|c|c|c|}
\hline Filsafat & Konstruktivisme & Kritis \\
\hline Epistemologis & $\begin{array}{l}\text { Transactionalist/ subjectivist: } \\
\text { pemahaman tentang suatu } \\
\text { realitas, atau temuan suatu } \\
\text { penelitian merupakan produk } \\
\text { interaksi antara peneliti dengan } \\
\text { yang diteliti. }\end{array}$ & $\begin{array}{l}\text { Transsactionalist/ Subjektivist: } \\
\text { Hubungan antara peneliti dengan } \\
\text { realitas yang diteliti selalu } \\
\text { dijembatani oleh nilai-nilai tertentu. } \\
\text { Pemahaman tentang suatu realitas } \\
\text { merupakan suatu realitas } \\
\text { merupakan value mediated findings. }\end{array}$ \\
\hline Ontologis & $\begin{array}{l}\text { Relativism: } \\
\text { realitas merupakan konstruksi } \\
\text { sosial kebenaran suatu realitas } \\
\text { bersifat relatif, berlaku sesuai } \\
\text { konteks spesifik yang dinilai } \\
\text { relevan oleh pelaku sosial. }\end{array}$ & $\begin{array}{l}\text { Historical realism: } \\
\text { Realitas yang teramati (virtual } \\
\text { reality) merupakan realitas "semu" } \\
\text { yang telah terbentuk oleh proses } \\
\text { sejarah dan kekuatan-kekuatan } \\
\text { sosial, budaya, dan ekonomi-politik. }\end{array}$ \\
\hline Aksiologis & $\begin{array}{l}\text { - } \\
\text { milai, etika, dan pilihan moral } \\
\text { terpisahkan dari suatu } \\
\text { penelitan. } \\
\text { Peneliti sebagai passionate } \\
\text { participant, fasilisator yang } \\
\text { menjembatani keragaman } \\
\text { subjektivitas pelaku sosial. } \\
\text { Tujuan penelitian: } \\
\text { rekonstruksi realitas sosial } \\
\text { secara dialektis antara } \\
\text { peneliti dengan pelaku sosial } \\
\text { yang diteliti. }\end{array}$ & $\begin{array}{l}\text { - Nilai, etika, dan pilihan moral } \\
\text { merupakan bagian tak } \\
\text { terpisahkan dari penelitian. } \\
\text { Peneliti menempatkan diri } \\
\text { transformative intellectual, } \\
\text { advokat, dan aktivis. } \\
\text { - Tujuan penelitian: kritik sosial, } \\
\text { transformasi, emansipasi, dan } \\
\text { social empowerment. }\end{array}$ \\
\hline Metodologis & $\begin{array}{l}\text { Reflective/ dialectical: } \\
\text { menekankan empati, dan } \\
\text { interaksi dialektis antara peneliti- } \\
\text { responden untuk merekonstruksi } \\
\text { realitas yang diteliti melalui } \\
\text { metode-metode kualitatif seperti } \\
\text { participant observation. } \\
\text { Kriteria kualitas penelitian: } \\
\text { Authenticity dan reflectivity; } \\
\text { sejauhmana temuan merupakan } \\
\text { refleksi otentik dari realitas } \\
\text { dihayati oleh para pelaku sosial. }\end{array}$ & $\begin{array}{l}\text { Participative: } \\
\text { Mengutamakan analisis } \\
\text { komprehensif, kontekstual, dan } \\
\text { multi-level analysis yang bisa } \\
\text { dilakukan melalui penempatan diri } \\
\text { sebagai aktivis/ partisipan dalam } \\
\text { proses transformasi sosial. } \\
\text { Kriteria kualitas penelitian: } \\
\text { Historical situatedness; sejauh mana } \\
\text { penelitian memperhatikan konteks } \\
\text { historis, sosial, budaya, ekonomi, } \\
\text { dan politik. }\end{array}$ \\
\hline
\end{tabular}


Dominasi penelitian komunikasi pada penelitian-penelitian yang berpijak pada asumsi, premis, serta kriteria paradigma klasik memang semangkin meningkat kualitas. Diantaranya dengan penerapan metode-metode analisis kuantitatif yang lebih maju dan semakin berkembangnya software analisis statistik selain SPSS seperti R-Studio, G Power, PSPP, Regressit, Salstat, dan seterusnya. Sehingga dapat memudahkan peneliti sosial sekalipun tidak mempunyai basic statistik yang baik dan juga dikembangkannya instrumen-instrumen pengukuran yang lebih valid dan reliable.

Perkembangan seperti itu memberikan kontribusi positif bagi perkembangan penelitian komunikasi. Namun, metodologi dari paradigma lain (konstrutivis dan kritis) sudah waktunya mendapatkan peluang agar dapat memperkaya varian, alternatif, sekaligus kontrol bagi penelitian paradigma klasik. Solusi atau jalan tengah peneliti bisa mengkombinasikan diantara metode penelitian kualitatif dan kuantitatif (Mixed Method), tentunya sesuai dengan kebutuhan atau keperluan penelitian itu sendiri.

\section{Penelitian Di Era Digital Dan Budaya Siber}

Perubahan paradigma ilmu komunikasi yang terkini terkait pengaruh dari teknologi komunikasi yang terus berkembang. Ada wacana menarik dari presiden Jokowi terkait pendirian fakultas Media Sosial, bahkan ada seminar yang diselenggarakan di Universitas Paramadina pada tanggal 27 Oktober 2017 terkait dengan wacana tersebut. Keberadaan (otologis) ruang virtual sudah semakin penting dan menjadi media saluran komunikasi yang dominan digunakan. Secara epsitemologi, contohnya bagaimana pengetahuan dicari, diandalkan melalui 'googling' untuk menjadikan sumber pengetahuan. Kecepatan mencari informasi melalui browsing bisa dikatakan masyarakat kita sudah berpola pikir 'Googlism'. Di dunia maya sampai ada komunitas yang menjadikan Google sebagai semacam agama Googlism, Google dianggap serba tahu sehingga menjadi tempat bertanya, berdo'a, dan mencari solusi dari segala masalah. Secara nilai (aksiologi) ada bisa positif dan negatif. Terjadi perubahan pola tingkah laku dan komunikasi mulai dari level antar pribadi, kelompok, organisasi, publik dan massa.

Budaya komunikasi pada dasarnya merupakan nilai - nilai yang muncul dari proses interaksi antar individu yang berlangsung secara terus menerus. Dalam tradisi antropologi, Cliffort Geerzt (dalam Martin dan Nakayama, 2007:47) mengartikan budaya sebagai nilai yang secara historis memiliki karakteristiknya tersendiri dan bisa dilihat dari simbol yang muncul. Simbol ini bermakna sebagai suatu sistem dari konsep ekspresi komunikasi diantara manusia yang mengandung makna dan yang terus berkembang seiring pengetahuan manusia dalam menjalani kehidupan ini. Cara berinteraksi tentunya dilandasi oleh nilai-nilai yang telah terkonstruksi di dalam diri digital natives sebagai sebuah determinasi dari penggunaan teknologi media baru. 
Tabel 3: Penerapan Teknologi Baru dalam Tingkat Tradisional (Mulyana, 2000)

\begin{tabular}{|l|l|l|}
\hline Tingkatan & Bentuk Tradisional & Penerapan Teknologi \\
\hline Antar Pribadi & Tatap muka, surat & $\begin{array}{l}\text { Telepon, hubungan kelompok } \\
\text { pribadi, } \\
\text { surat elektronik, voicegram }\end{array}$ \\
\hline Kelompok & Tatap muka & $\begin{array}{l}\text { Konferensi telepon, } \\
\text { telekomunikasi komputer }\end{array}$ \\
\hline Organisasi & $\begin{array}{l}\text { Tatap muka, memo, } \\
\text { pertemuan } \\
\text { elektronik, telepon, surat } \\
\text { manajemen dengan bantuan } \\
\text { komputer, sistim informasi, } \\
\text { faksimil }\end{array}$ \\
\hline Massa/ Publik & $\begin{array}{l}\text { Surat kabar, majalah, buku, } \\
\text { televisi, radio, film } \\
\text { kabel, tv satelit } \\
\text { langsung, videoteks, } \\
\text { teleteks, sistem informasi } \\
\text { digital }\end{array}$ \\
\hline
\end{tabular}

Tabel 3 menggambarkan teknologi-teknologi baru yang berhubungan dengan tingkat komunikasi tradisional. Bentuk komunikasi yang dilakukan pada bentuk tradisional telah mengalami pergeseran akibat penerapan teknologi. Bentuk komunikasi dilandasi oleh nilai-nilai dan cara berinteraksi yang dibangun karena penerapan teknologi ini akan membangun sebuah budaya pada generasi melek teknologi.

Hal yang positif adalah adanya kemudahan, kecepatan akses komunikasi yang tidak lagi dibatasi ruang dan waktu. Begitu pula penyebaran pengetahuan yang cepat dan selalu update terjadi dengan teknologi ini. Media sosial semakin penting dalam kehidupan manusia sebagai media berkomunikasi lintas batas waktu dan tempat apalagi dengan semakin berkembangnya teknologi smartphone. Lalu pengaruh nilai yang negatif contohnya adalah begitu mudahnya penyebaran konten-konten negatif seperti pornografi, kekerasan, teroris sehingga dapat dengan mudah diakses oleh siapa saja.

Perpaduan paradigma Positivis, konstruktivis, kritis terjadi dalam penelitian atau pengamatan di ruang virtual (dunia maya) yang terfasilitasi dengan internet. Ruang untuk mengungkapkan pendapat sudah terbuka dengan adanya media sosial. Istilah tranding topic, viral yang merupakan arus dari opini publik di dunia maya dari Netizen (warganet). Setiap orang bisa berbicara, berpendapat, meng-like, share, memberikan komentar (comment), sehingga dapat terukur secara kuantitatif, seperti berapa yang meng-klik like, berapa kali di-share dan seterusnya. Analisis jaringan sosial atau komunikasi juga bisa dilakukan dengan menggunakan software NodelX sebuah program yang diciptakan oleh microsoft khusus menganalisis jaringan sosial/ komunikasi di sosial media dengan menggunakan pendekatan kuantitatif. Ada pula metode pendekatan penelitian di internet secara kualitatif, yaitu Netnografi atau dengan istilah 'Etnongrafi Virtual'. Netnografi adalah metode etnografi di dunia virtual dengan objek penelitiannya adalah kelompok dan budaya yang terjadi disana. 
Komunikasi introvert, yaitu suatu kecenderungan seseorang yang pendiam dan pasif berbicara dimuka umum tapi lebih banyak mencurahkan hatinya dalam tulisan seperti buku diary, dengan adanya media sosial lebih leluasa menyampaikan curhatannya, bahkan segala aktivitas selalu di posting update di media sosial. Jadi dengan adanya sosial media keberanian mengirim pesan terpendam bisa memungkinkan.

Feedback atau partisipasi komunikan menjadi lebih terbuka. Komunikasi antarpribadi (keintiman) juga terjadi dengan terfasilitasi ruang virtual (media sosial) contoh kasus banyak kasus yang diberitakan media perkenalan di facebook yang akhirnya ada yang sampai menikah, ada yang tertipu, bahkan sampai memicu permusuhan. Sisi negatif dari komunikasi di media sosial adalah adannya potensi gangguan (noise) dalam berkomunikasi, karena banyak penelitian sudah mengungkapkan gangguan komunikasi yang tervasilitasi media atau tools. Karena komunikasi berlangsung tanpa tatap muka, maka keseluruhan pesan tidak dapat diidentifikasi oleh pengirim maupun penerima pesan, terutama pesan non verbal seperti gestur, mimik muka yang kecenderungannya lebih jujur daripada verbal baik ucapan dan tulisan.

\section{Tokoh-Tokoh Dan Lembaga Pendukung Paradigma Baru}

Prof. Dr. H. Engkus Kuswarno, MS (Universitas Padjadjaran) memaparkan perubahan paradigma penelitian komunikasi pada bab akhir buku "Metode Penelitian Komunikasi" tahun 2007, yaitu buku kompilasi dari beberapa pakar baik dalam dan luar negeri. Analisisnya secara historical selama kurun waktu 40 tahun lebih perubahan paradigma dalam penelitian di Indonesia. Ada tiga periode perubahan, yaitu: pertama, periode tahun 1960 - 1980; kedua, periode 1980 - 1990, dan ketiga, periode 1990 - 2000 (Kurwarno, 2008: 413-428).

Periode tahun 1960-an sampai awal tahun 1980-an, yang dapat disebut sebagai periode Deskriptif. Indikator penelitian komunikasi dapat dilihat pada jenis penelitian untuk penulisan skripsi. Pada periode ini kebanyakan mahasiswa melalukan penelitian dengan menggunakan pendekatan deskriptif. Situasi ini memungkinkan demikian, karena sejak awal berdiri penyelenggara pendidikan ilmu komunikasi baik di UNPAD, UI dan UGM yang dulu bernama Fakultas atau jurusan Jurnalistik dan Publistik, sebagian mahasiswanya adalah karyasiswa. Mereka bekerja di beberapa instansi dalam bidang Hubungan Masyarakat, Departemen Penerangan atau wartawan media cetak dan elektronik (radio), sehingga tren penulisan skripsi bertujuan menggambarkan fakta-fakta di instansi tempat mereka bekerja. Pada awal tahun 1980-an tradisi ini masih berlanjut dengan penelitian 'dari instansi ke instansi' dengan tema yang relatif serupa.

Metode deskriptif bisa disebut dengan "metode hemaprodit", karena menggunakan sifat data yang berbeda atau gabungan kuantitatif dan kualitatif. Sehingga ada dua sebutan yang berbeda yaitu: 1) Deskriptif Kuantitatif; dan 2) 
Deskriptif Kualitatif. Buku yang dirujuk oleh mahasiswa publistik pada masa itu diantaranya buku-buku yang ditulis Astrid S. Soesanto dan Onong Uchyana Effendy, keduanya adalah mantan Fikom UNPAD. Keduanya sangat produktif menulis kajian komunikasi pada saat itu. Periode ini adalah peralihan dari Publistik ke ilmu komunikasi. Ada dua pandangan yang terinternalisasi dalam buku-buku yang ditulis oleh mereka, Astrid merupakan lulusan Jerman di Universitat Munster (1960) dan Freie Universitat (1964). Sedangkan Onong Iulusan Bowling Green State University, Ohio, Amerika Serikat. Maka kiblat ilmu komunikasi secara literasi sangat diwarnai wawasan dan gagasan Jerman (dulu Jerman Barat) dan Amerika.

Periode tahun 1980-an sampai akhir 1990-an, penelitian komunikasi banyak menggunakan pendekatan kuantitatif (klasik atau positivistik). Metode kolerasional menjadi sangat populer, sehingga masa itu dapat disebut "Periode Korelasional". Terjadi perubahan drastis dari penelitian deskriptif menjadi penelitian korelasional pada sekitar pertengahan tahun 1980-an setelah Prof. Dr. Jalaluddin Rakhmat, M.Sc pulang dari studinya di lowa University, Amerika Serikat. Dengan perhitungan statistik sebagai alat analisis data yang diperoleh dari mata kuliah Metode Penelitian Komunikasi (MPK) ditandai dengan diterbitkannya buku "Metode Penelitian Komunikasi" pada tahun 1984, yang sebelumnya hanya ada Metode Penelitian Sosial (MPS). Sebagian besar mahasiswa pada saat itu melalukan penelitian dengan menggunakan metode korelasional dan sedikit eksperimental. Rentang waktu tersebut disebut juga Periode Jalaluddin Rakhmat, walaupun belakangan beliau justru memberikan kritikan terhadap paradigma positivistik yang pernah dikembangkannya).

Periode tahun 1990-an sampai 2000-an, terjadi lompatan besar dengan ditandai perubahan paradigma kuantitatif ke kualitatif. Sehingga disebut Periode Kualitatif dengan Perspektif Konstruktivis (pendekatan fenomeologis dan interaksionisme simbolik) dan Perspektif Kritis. Perubahan terutama sangat menonjol setelah terbitnya buku Prof. Dr. Deddy Mulyana, MA, "Metodologi Penelitian Kualitatif: Paradigma Baru IImu Komunikasi dan IImu Sosial laninya" (2001), terutama dikalangan Fikom UNPAD. Deddy lulusan Northern Illionis University, Amerika (1986) Master, dan Ph.D di Monash University, Autralia (1995) ini membawa perubahan paradimatik dalam penelitian para mahasiswa komunikasi di semua strata (S1, S2, dan S3) di berbagai Universitas di Indonesia. Karena semakin banyaknya mahasiswa melakukan penelitian dengan pendekatan kualitatif, maka bisa dikatakan bahwa periode ini disebut Periode Deddy Mulyana. Sebenarnya, sejak tahun 1990-an juga telah mengintensifkan penggunaan metode penelitian kualitatif dalam penulisan skripsi, tesis, dan disertasi di kalangan mahasiswa, khususnya analisis framing dan analisis wacana kritis. Sebagian dari karya ilmiah mereka diterbitkan dalam jurnal Penelitian Ilmu Komunikasi Thesis yang diterbitkan oleh Departemen Ilmu Komunikasi FISIP UI. Ketua Redaksi nya adalah Dedy N. Hidayat, Ph.D dan juga Prof. Deddy Mulyana salah seorang penyuntingnya. Dedy N. Hidayat adalah penggerak utama paradigma interpretatif di lembaga tersebut, pakar komunikasi yang awalnya, seperti Jalaluddin Rakhmat (positivis). Intensitas 
penggunaan Analisis Framing dan Analisis Wacana Kritis juga didorong antara lain oleh dua buka yang ditulis oleh lulusan IImu Komunikasi Fisipol UGM, Eriyanto: Analisis Wacana yang diberi kata pengantar oleh Dedy N. Hidayat, dan Analisis Framing yang diberi pengantar oleh Deddy Mulyana; juga oleh buku Alex Sobur: Analisi Teks Media (2001).

Periode kekinian atau istilah yang sedang tren adalah "zaman now", 2000-an sampai saat ini. Holmes (2012) dalam bukunya "Media, Teknologi, dan masyarakat", menyatakan bahwa orang yang hidup dalam information society tidak hanya bertemu dan menggunakan teknologi-teknologi informasi dan komunikasi, melainkan cara tindakan mereka semakin dibingkai oleh teknologi tersebut. Hal ini menimbulkan pergeseran budaya komunikasi pada era konvensional menuju era media baru. Oleh karena itu, berdasarkan perubahan ini, maka terjadi pula perubahan dengan metode penelitian yang didasari oleh pergeseran budaya komunikasi yang terjadi oleh digital natives di era media baru. Muncul kajian-kajian dengan teknik yang beradaptasi dengan perkembangan penggunaan media. Dr. Rulli Nasrullah, M.Si sebagai yang memulai tulisan dalam konteks penelitian di era digital dan penggunaan media baru di Indonesia. Diantara buku-bukunya adalah: Etnografi Virtual: Riset Komunikasi, Budaya, dan Sosioteknologi di Internet (2016), Media Sosial: Perspektif Komunikasi, Budaya, dan Sosioteknologi (2015), Teori dan Riset Media Siber (2012), Komunikasi Antar Budaya di Era Budaya Siber (2012).

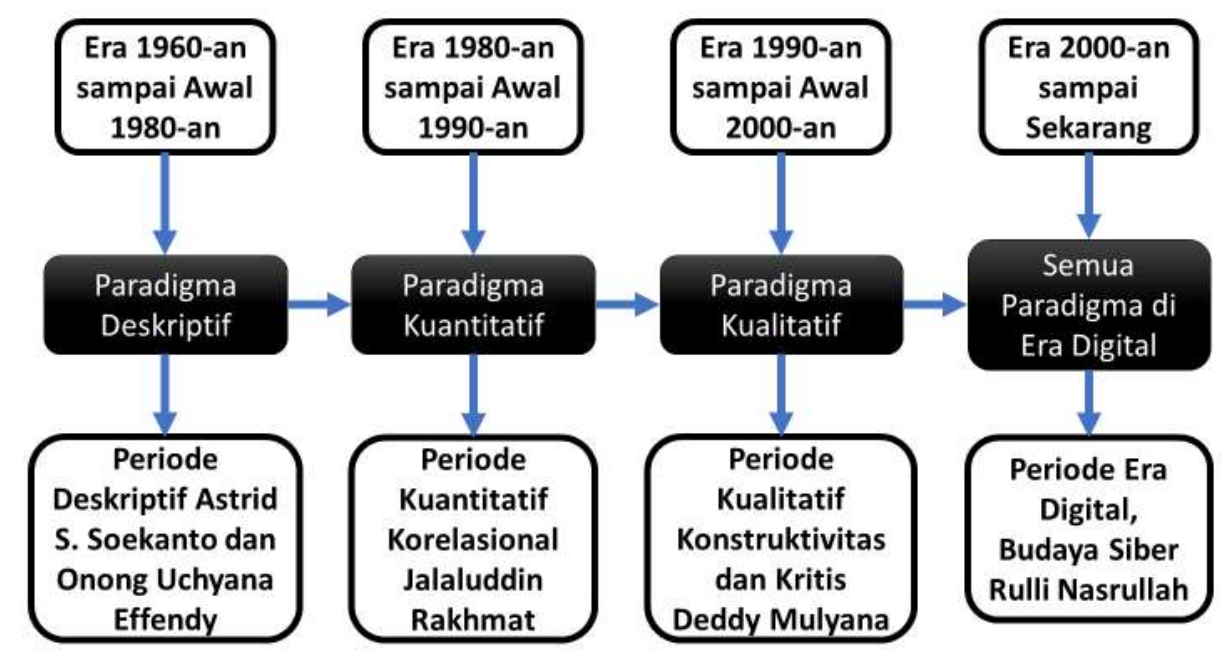

Gambar 1: Perubahan Paradigmatik Penelitian Komunikasi (Era 1960-an sampai Sekarang/ 2017).

\section{Proses “Pengujian" Terhadap Paradigma Baru}

Pertama, pengujian terhadap paradigma baru adalah untuk membuktikan esensi paradigma tersebut yang terjadi saat ini. Pertama, dilakukan dengan menampilkan bukti atau data yang bersumber dari literatur. Seperti yang dipaparkan 
oleh Kuswarno (2008), dimana dimensi-dimensi perubahan paradigma penelitian sudah terjadi khususnya contoh yang ada di UNPAD seperti yang akan dirangkum dibawah ini, yaitu:

1. Pemilihan tema pemilihan lebih beragam. Jika pada era 1960-an hingga 1980-an penelitian komunikasi lebih berorientasi kepada perpindahan dari 'instansi ke instansi', atau era 1980-an hingga 1990-an menghubungkan variabel apa saja dengan variabel lainnya. Maka akhir era 1990-an sampai sekarang tema penelitian lebih beragam. Mahasiswa lebih berani melalukan penelitian kepada komunitas yang dianggap sebuah subkultur, atau deviant, misalnya komunitas kaum pengemis (Kuwarno, 2004), tuna netra, anak autis (Antin, 2005), orang latah (Sukaesih, 2004), tuna runggu, penderita kusta (Teja, 2006), pencandu narkoba (Rahman, 2004), komunitas bertato (Gumilar, 2007), kehidupan waria, dan seterusnya. Penelitian komunikasi organisasi / Public Relations yang sebelumnya dominan objektif, berubah menjadi subjektif. Juga penelitan tentang efek media massa menurun popularitasnya, berubah menjadi penelitian fenomenologi, interaksionis atau dramaturgis dalam komunikasi interpersonal, kelompok, intra dan antrbudaya. Penelitian teks media, analisis isi, semiotika, framing dan juga analisis wacana kritis begitu digandrungi para mahasiswa UNPAD

2. Konsep "masalah penelitian" lebih luas. Pada era 1960-an hingga 1980-an atau 1980 - 1990, salah satu prinsip populer untuk menyebut masalah adalah adanya 'kesenjangan antara harapan dan kenyataan'. Saat itu bila usulan penelitian tidak mengungkapkan kesenjangan ini, maka penelitian tidak bisa dilanjutkan. Pada era 2000-an, konsepsi masalah semakin meluas. Sesuatu yang langka, unik, berbeda, belum pernah ada dilakukan penelitian, atau karena kekhasan komunitas tertentu, dapat menjadi 'masalah penelitian' dan menjadi salah satu alasan mengapa penelitian dilakukan, terlepas dari apakah peneliti melihat ada atau tidak ada kesenjangan antara harapan dan kenyataan. Mengungkap kehidupan pengemis, misalnya. Didasari bukan karena peneliti menganggap mereka menjadi masalah bagi orang lain, atau ada masalah dengan keberadaan mereka. Peneliti ingin tahu dan mengungkap lebih jauh tentang kekhasan dan keunikan kehidupan pengemis dari sudut pandang mereka, termasuk kemungkinan terdapat masalah yang pengemis rasakan dan perlu mereka sampaikan termasuk solusi.

3. Perubahan dari variabel ke konsep. Terdapat tradisi yang khas pada era 1980-an hingga 1990-an untuk menjelaskan tema atau judul dengan berstandar pada 'harus minimum dua variabel'. Untuk penelitian kuantitatif memang demikian, tapi tidak untuk penelitian kualitatif. Lain juga halnya dengan penelitian metode mixed method / 'hemaprodit' deskriptif yang boleh hanya menyebut satu variabel (yang kadang diuraikan menjadi subvariabel-subvariabel). Penelitian kualitatif tidak familiar dengan variabel, melainkan lebih akrab dengan istilah 'konsep' atau 'konteks'. Agak janggal 
jika disebut "penelitian kualitatif boleh hanya satu variabel, dengan beberapa sampai puluhan subvariabel." Kalimat itu mencerminkan "menjelaskan kualitatif dengan sudut pandang kuantitatif." Dengan demikian, mahasiswa tidak mengalami stress jika harus mencari kekurangan satu variabel. Dengan konsep atau konteks yang jelas, mereka dapat melaksanakan penelitian itu.

4. Laporan penelitian lebih tebal. Walaupun belum tentu mencerminkan kualitas hasil peneltian, ketebalan laporan penelitian pada skripsi, tesis, dan disertasi menjadi ciri 'keberanian' dan 'kreativitas' mahasiswa komunikasi dalam menulis hasil penelitian mereka. Laporan penelitian mahasiswa era 2000-an yang ditandai dengan paradigma kualitatif, rata-rata lebih tebal dan lebih beragam analisisnya. Ketebalan hasil penelitian kualitatif (thick description menurut istilah Clifford Geertz) memang diisyaratkan untuk menunjukkan orisinalitas data.

5. Pemilihan metode atau pendekatan lebih beragam. Mahasiswa yang memilih paradigma atau perspektif kualitatif lebih beragam memilih pendekatan atau tradisi seperti yang disebut Creswell (1998), misalnya fenomenologi, interaksi simbolik (termasuk dramatrugi), studi kasus, dan etnografi. Analisis framing yang dipengaruhi perspektif konstruktivis, yang dirumuskan Peter Berger dan Thomas Luckmann dalam buku mereka The Social Construction of Reality (1966) dan analisis wacana kritis (critical discourse analysis), yang merupakan turunan perspektif kritis, terutama model Teun Van Dijk, juga banyak digunakan. Penelitian kualitatif lewat fenomenologi dan interaksi simbolik khususnya (dengan model penelitian bersifat induktif) tentu saja memberi peluang ditemukannya konsep baru atau teori baru, karena pada hakikatnya paradigma kualitatif sangat relevan untuk membangun teori ketimbang menguji teori.

Kedua, pengujian akan dilakukan penulis terkait komunikasi di era digital. Metode penelitian dengan memanfaatkan teknologi akhirnya memungkinkan peneliti bisa melakukan penyebaran kuisioner secara online dengan menggunakan google formulir. Sehingga link daftar pertanyaan (kuisioner) dapat disebarluaskan melalui group Whatsapp, Facebook, atau melalui jaringan pribadi (japri). Lalu responden tinggal mengisi secara online. Observasi dan wawancara pun bisa dilakukan secara online sesuai kaidah metodologi Netnografi. Menurut Kozinets (Nasrullah, 2017), pengumpulan data netnografi (etnografi virtual) ada dua tipe. Pertama, data yang berasal dari komunikasi langsung dengan anggota komunitas virtual. Kedua, data yang didapat dari hasil observasi atau pengamatan, yaitu data yang dikumpulkan oleh peneliti terhadap komunitas virtual. Pengumpulan tersebut dilakukan dengan cara observasi dan wawacara melalui media internet dan bisa tanpa ketemu langsung, bisa melalui email, video call, atau melalui media sosial (facebook, whatsapp contohnya). Berikut observasi data pendahuluan dan interaksi dengan CEO sebuah startup yang sedang mengikuti lomba di Indonesia. 


\section{Daftar Pustaka}

Agusta, Ivanovich. 2014. Paradigma Metodologi Illmu Sosial: Simpang Jalan Konstruksi Teori. Bogor: IPB Press

Imran, Hasyim Ali. 2014. Pengantar Filsafat Ilmu Komunikasi. Jakarta: PT. Grasindo

Littlejohn, Stephen W dan Karen A. Foss. 2009. Teori Komunikasi: Theories of Human Communication. Jakarta: Salemba Humanika

Mulyana, Deddy. 1999. Kendala-kendala Pengembangan Penelitian Komunikasi di Indonesia. Jurnal Ikatan Sarjana Komunikasi Indonesia, Vol III/ April/ 1999. (ISSN 0853-4470). Bandung: Remaja Rosdakarya

. 2000. Human Communication, Konteks-Konteks Komunikasi. Bandung : Remaja Rosdakarya

Mulyana, Deddy, dan Solatun, Metodogi Penelitian Komunikasi: Contoh-contoh Penelitian Kualitatif dengan Pendekatan Praktis, Bandung: Remaja Rosdakarya

Nasrullah, Rulli. 2014. Teori dan Riset Media Siber (Cybermedia). Jakarta : Kencana - 2017. Etnografi Virtual: Riset Komunikasi, Budaya, dan Sosioteknologi di Internet. Bandung: Simbiosa Rekatama Media

Rakhmat, Jalaluddin. 1999. Kritik Paradigma Pasca-Positivisme terhadap Positivisme. Bandung: Remaja Rosdakarya

Shahreza, Mirza dan Korry El-Yana. 2016. Etika Komunikasi Politik. Tangerang: Indigo Media.

Suhartono, Suparlan. 2005. Filsafat Ilmu Pengetahuan. Yogyakarta: Ar Ruzz 